\title{
Radioterapia u pacjentów geriatrycznych
}

\author{
Justyna Danielska, Justyna Chałubińska-Fendler, Jacek Fijuth
}

W związku z szybkim starzeniem się społeczeństwa w najbliższych latach wykrywalność chorób nowotworowych będzie w 70\% dotyczyć osób po 65 roku życia. Wybór leczenia w tej populacji powinien być ukierunkowany na wydłużenie życia oraz podniesienie jego jakości. Chorzy w wieku podeszłym rzadko są włączani do badań klinicznych. Istnieje pilna potrzeba przeprowadzenia badań klinicznych obejmujących pacjentów powyżej 65 roku życia, które pomogłyby ustalić korzyści leczenia w tej grupie chorych. Podstawową zasadą leczenia onkologicznego u osób starszych powinien być wybór najlepiej tolerowanej metody leczenia. Ryzyko powikłań po radioterapii wzrasta wraz z liczbą chorób ogólnych pacjenta, dlatego ważna jest precyzyjna kwalifikacja do radioterapii w oparciu o odpowiednie skale oceny geriatrycznej. Całościowa ocena geriatryczna jest zintegrowanym procesem diagnostycznym pomagającym ustalić możliwości zapewnienia dalszego leczenia.

\section{Radiotherapy in the elderly patients}

Increasing age is directly associated with the increasing rates of cancer. The over-65-year-old group will account for $70 \%$ of people with newly diagnosed cancer. The selection of treatment options should be based on the prolongation of life expectancy and overall increase in the quality of life. There is a limited number of radiation oncology clinical trials designed strictly for the elderly patients. Prospective clinical trials for the elderly are critical to develop relevant data that oncologists would apply in their everyday practice. Older patients have variable health status, thus it is crucial to integrate geriatric evaluation into oncology decision-making process. A comprehensive geriatric assessment is a multidimensional, interdisciplinary diagnostic process designed to improve the effectiveness and tolerance of the treatment in the elderly.

NOWOTWORY Journal of Oncology 2015; 65, 4: 266-270

Słowa kluczowe: choroba nowotworowa, geriatria, radioterapia

Key words: cancer, geriatrics, radiotherapy

\section{Wstęp}

Współczesny postęp medycyny oraz zastosowanie metod profilaktyki zdrowotnej sprawiły, że pacjenci w wieku podeszłym stanowią coraz większą grupę osób kwalifikujących się do leczenia radioterapeutycznego.

Chory w wieku podeszłym to osoba, która ma ukończone co najmniej 65 lat. Grupa tych chorych jest jednak bardzo heterogenna, co wynika z indywidualnego procesu starzenia oraz z występowania u każdej osoby innych przewlekłych procesów chorobowych bądź stosowania szerokiej gamy leków.
Polskie społeczeństwo szybko się starzeje. Według danych Głównego Urzędu Statystycznego osoby, które ukończyły 65 rok życia, stanowiły w 2013 roku ok. 15\% ogólnej populacji. Szacuje się, że odsetek ten wzrośnie do 21\% w 2025 roku. Według prognoz na 2025 rok nastąpi 50-procentowy przyrost ludności w przedziale wiekowym między 65 a 70 rokiem życia i 100-procentowy w przedziale 70-80 lat. Opracowania epidemiologiczne wskazują, że 65\% nowotworów wykrywanych jest u osób po 65 roku życia. W 2012 roku w Europie nowotwory wykryto u 1,6 miliona ludzi po 65 roku życia. Wykrywalność chorób nowotworowych

Zakład Radioterapii

Uniwersytet Medyczny w Łodzi 
w 2020 roku wzrośnie o ponad 200 tysięcy w porównaniu z rokiem 2012 [1].

Celem leczenia onkologicznego powinno być przywrócenie choremu dobrostanu fizycznego, psychicznego i społecznego. Celem terapii powinno być maksymalne wydłużenie życia oraz podniesienie jego jakości przy możliwie jak najniższym dyskomforcie związanym z proponowanym leczeniem.

Najważniejszymi wyzwaniami współczesnej onkologii są wydłużenie czasu przeżycia bez progresji choroby oraz zmniejszenie toksyczności leczenia.

Osoby starsze mają mniejsze zdolności regeneracyjne komórek niż osoby młode, więc są bardziej narażone na działania niepożądane radioterapii występujące pod postacią odczynu popromiennego [2]. Celem niniejszej pracy jest przedstawienie poglądów dotyczących stosowania radioterapii u pacjentów geriatrycznych.

\section{Rak piersi}

Wiek stanowi jeden z najważniejszych czynników ryzyka zachorowania na raka piersi. Kobiety w wieku powyżej 65 lat stanowią obecnie 35-50\% chorych na raka piersi. W porównaniu z pacjentkami młodszymi kobiety powyżej 75 roku życia otrzymują mniej agresywne leczenie, i wskaźniki umieralności są u nich wyższe [3-5]. Standardowymi czynnikami prognostycznymi w raku piersi, obok wieku, są: status węzłów chłonnych pachowych, rozmiar guza, inwazja naczyń, stopień histologicznego zaawansowania, typ histologiczny nowotworu, status receptorowy, odpowiedź guza na leczenie neoadiuwantowe oraz ekspresja genu HER2.

Cancer and Leukemia Group B (CALGB) przeprowadziło randomizowane badanie (CALGB; trial 9343) porównujące skuteczność leczenia samodzielną hormonoterapią z leczeniem skojarzonym z tamoxifenem oraz radioterapią u starszych pacjentek (> 70 r.ż) chorych na raka piersi w pierwszym stopniu zaawansowania z dodatnimi receptorami estrogenowymi. W grupie, w której zastosowano radioterapię wraz z hormonoterapią, zaobserwowano w okresie 10 lat obserwacji o 8\% mniej wznów miejscowych oraz o 7\% mniej ipsilateralnych wznów raka piersi. Zastosowanie radioterapii w tej grupie wydaje się nie mieć wpływu na całkowity czas przeżycia, odległe przeżycia wolne od choroby oraz konieczność wykonania mastektomii. Wynik niniejszego badania podkreśla znaczenie wpływu innych przewlekłych procesów chorobowych na przeżywalność w tej grupie pacjentek. $\mathrm{U}$ chorych powyżej 70 roku życia rezygnacja z radioterapii możliwa jest w pierwszym stopniu zaawansowania choroby, przy dodatnich receptorach estrogenowych i progesteronowych, ujemnych marginesach po tumorektomii oraz przy spodziewanej możliwości przeprowadzenia 5-letniej hormonoterapii [6].

\section{Rak odbytnicy}

Rak jelita grubego należy do jednych z najczęściej rejestrowanych nowotworów złośliwych w Polsce i na świecie [7]. Około $80 \%$ przypadków raka odbytnicy występuje u osób starszych; $50 \%$ u pacjentów powyżej 70 roku życia i $20 \%$ u pacjentów powyżej 80 roku życia [8]. Tylko $25 \%$ pacjentów kwalifikowanych do badań klinicznych to osoby w wieku podeszłym. Populacja osób starszych jest niedostatecznie reprezentowana w grupie pacjentów objętych badaniami klinicznymi [9]. Wiąże się z tym deficyt danych dotyczących tolerancji i efektów leczenia w tej grupie chorych.

W literaturze znajdujemy głównie badania retrospektywne oceniające skuteczność leczenia radioterapeutycznego u starszych chorych na raka odbytnicy.

Pasetto i wsp. przeprowadzili retrospektywną analizę porównującą toksyczność i możliwość zastosowania radiochemioterapii u starszych pacjentów, których podzielili na dwie grupy: "fit" i „vulnerable" [10]. Do kategorii "fit" zakwalifikowano chorych bez dodatkowych obciążeń lub z jedną chorobą współistniejącą w 1. stopniu zaawansowania, a do kategorii „vulnerable" - chorych z jedną lub więcej niż jedną chorobą dodatkową w stopniu zaawansowania 2 lub 3. Drugorzędowym punktem końcowym tego badania był wpływ występowania chorób współistniejących na przebieg i tolerancję leczenia radiochemioterapeutycznego. Choroby współistniejące zostały ocenione na podstawie Cumulative Illness Rating Scale-Geriatric - CIRS-G.

Według retrospektywnego badania Pasetto i wsp. starsi chorzy, zarówno "fit"jak i „vulnerable", na miejscowo zaawansowanego raka odbytnicy mogą zostać bezpiecznie poddani przedoperacyjnej radiochemioterapii (z 5-fluorouracylem) lub krótkiej przedoperacyjnej radioterapii, ponieważ w obu grupach chorych tolerancja i odpowiedź na leczenie była podobna. Wiek pacjenta nie powinien być przyczyną zaniechania zastosowania leczenia adiuwantowego, neoadiuwantowego czy paliatywnego. Nie powinien również mieć wpływu na zmniejszenie dawki leków cytotoksycznych [10].

Margalit i wsp. przeprowadzili retrospektywną analizę pacjentów powyżej 75 roku życia leczonych adiuwantową lub neoadiuwantową radiochemioterapią, która wykazała konieczność wcześniejszego zakończenia leczenia, obniżenia dawki bądź wprowadzenia modyfikacji do zaplanowanego schematu radiochemioterapii u większości pacjentów. Wskazywali oni na konieczność ostrożnego prowadzenia intensyfikacji leczenia skojarzonego u starszych pacjentów [11].

Neugut i wsp. w swoim badaniu stwierdzili, że pooperacyjna chemioterapia i radioterapia zastosowana u pacjentów tzw. "fit" z chorobą w III stopniu zaawansowania poprawia całkowite przeżycia [12].

Colorectal Cancer Collaborative Group opublikowała dane wskazujące, że radioterapia śródoperacyjna obniża 
ryzyko wystąpienia wznowy miejscowej oraz śmierci niezależnie od wieku pacjenta [13].

Podsumowując, we wszystkich badaniach podkreślana jest potrzeba przeprowadzenia prospektywnych badań w grupie chorych powyżej 65 roku życia z oceną tolerancji leczenia i wpływu chorób towarzyszących na rokowanie.

\section{Nowotwory regionu głowy i szyi}

Nowotwory nabłonkowe regionu głowy i szyi są najczęstsze u osób między piątą a szóstą dekadą życia. 25\% chorych to osoby w wieku podeszłym [14].

Pignon i wsp. w badaniu prospektywnym wykazali, że chorzy powyżej 70 roku życia poddani radykalnej radioterapii osiągają analogiczne przeżycia całkowite jak młodsi. Ryzyko wystąpienia ostrego odczynu popromiennego ze strony błony śluzowej jest u nich wyższe, natomiast późnej reakcji — analogiczne jak w grupach niższych wiekowo [15].

Dotychczas oceniono zbyt mało pacjentów w grupie wiekowej powyżej 70 roku życia, aby jednoznacznie stwierdzić, czy pooperacyjna radiochemioterapia z dodatkiem cisplatyny w rakach płaskonabłonkowych regionu głowy i szyi przynosi poprawę przeżyć całkowitych $[16,17]$.

Metaanaliza przeprowadzona przez Pignona i wsp. wykazała, iż chorzy powyżej 70 roku życia nie odnosili korzyści $z$ radioterapii w połączeniu z chemioterapią [18].

Forastiere i wsp. opublikowali badanie porównujące zastosowanie równoczesnej radiochemioterapii z dodaniem cisplatyny do samodzielnej radioterapii w raku krtani u osób przed i po 60 roku życia. Wykazało ono wyższy odsetek pacjentów niewymagających laryngektomii w przypadku stopnia zaawansowania T2 i T3 przy zastosowaniu jednoczesnej radiochemioterapii niż wyłącznej radioterapii w obu grupach badanych [19].

Kilka badań retrospektywnych opisuje występowanie zwiększonego ryzyka pojawienia się późnej reakcji popromiennej wywołanej zastosowaniem radiochemioterapii u starszych chorych [20,21].

Brakuje danych na temat skuteczności leczenia i tolerancji radioterapii w połączeniu z cetuksymabem u chorych powyżej 64 roku życia z miejscowo zaawansowanym rakiem regionu głowy i szyi [22].

Według zaleceń Towarzystwa Onkologii Geriatrycznej (SIOG) podstawą kwalifikacji chorych starszych do agresywnego leczenia promieniowaniem jonizującym jest ocena ich stanu ogólnego oraz występowania chorób współistniejących. U chorych w dobrym stanie klinicznym postępowaniem z wyboru jest radioterapia radykalna z użyciem technik IMRT (Intensity Modulated Radiation Therapy), pozwalających dostosować przestrzenny rozkład dawki do kształtu napromienianego obszaru z maksymalną ochroną narządów krytycznych [23].

\section{Nowotwory mózgu}

Wraz ze starzeniem się społeczeństwa wzrasta zapadalność na pierwotne nowotwory mózgu [24].

Chirurgia pozostaje podstawową metodą leczenia glejaków wielopostaciowych i gwiaździaków anaplastycznych. Pooperacyjna radioterapia lub radiochemioterapia $z$ temozolomidem są metodami poprawiającymi odpowiedź kliniczną na leczenie [25-27]. Niewielkie randomizowane badanie (85 pacjentów w wieku powyżej 75 lat) wykazało, że radioterapia u starszych chorych nie wiązała się z wystąpieniem poważnych działań niepożądanych, obniżeniem jakości życia czy funkcji poznawczych.

Dla pacjentów powyżej 64 roku życia z glejakiem i gwiaździakiem anaplastycznym po zabiegu operacyjnym monoterapia temozolomidem i radioterapia pozostają równoważne jako samodzielne metody leczenia [28].

Kolejne badanie udowodniło, że pooperacyjna radioterapia (shorter-course) jest rozsądną opcją terapeutyczną dla chorych powyżej 70 roku życia [29].

\section{Rak stercza}

Ponad 70\% pacjentów w momencie rozpoznania raka stercza ma więcej niż 65 lat. W przypadku raka stercza parametr wieku nie jest czynnikiem rokowniczym ani predykcyjnym. Postępowanie w raku stercza u starszych mężczyzn jest podobne do tego u młodszych. Przy wyborze postępowania leczniczego istotne jest spodziewane przeżycie chorego. U chorych starszych, z istotnymi klinicznie obciążeniami internistycznymi, a szczególnie z przeciwwskazaniami do radykalnej prostatektomii, zalecana jest radioterapia radykalna, również w połączeniu z hormonoterapią [30]. Stosowanie hormonoterapii u starszych pacjentów wiąże się ze zwiększonym ryzykiem złamań [31]. Według zaleceń National Comprehensive Cancer Network leczenie bezobjawowych pacjentów z oczekiwanym czasem przeżycia wynoszącym 5 lat lub mniej powinno zostać odroczone do czasu pojawienia się objawów klinicznych choroby. U pacjentów z czynnikami wysokiego ryzyka pojawienia się przerzutów w ciągu 5 lat (cecha T3-T4, indeks Gleasona 8-10) należy rozważyć zastosowanie radioterapii i hormonoterapii [32].

\section{Komentarz}

Współczesne techniki napromieniania takie jak IMRT lub inne wysoce konformalne techniki, jak np. VMAT (Volumetric Arc Therapy) albo radioterapia stereotaktyczna z użyciem CyberKnife ${ }^{\circledR}$, pozwalają na bardzo precyzyjne kształtowanie rozkładu dawki wokół guza nowotworowego z jednoczesną ochroną tkanek zdrowych. Technika napromieniania w oparciu o modulację intensywności wiązki pozwala na napromienianie zmian nowotworowych zlokalizowanych w miejscach, które dotychczas były dostępne radiotera- 
pii przy wyższym ryzyku powikłań popromiennych. Dzięki wprowadzeniu nowoczesnych technik radioterapii możliwe jest zastosowanie intensywnych schematów leczenia, wydłużających czas przeżycia chorego. Podstawową zasadą leczenia onkologicznego u osób starszych powinien być wybór najlepiej tolerowanej metody leczenia. Chory powinien aktywnie uczestniczyć w wyborze terapii i we współpracy z lekarzami dopasować optymalną metodę leczenia. Należy pamiętać, że często dla pacjenta ważniejsze jest zachowanie dobrej jakości życia, nawet kosztem rezygnacji z wydłużenia czasu przeżycia. Bardzo istotne jest zapobieganie niepełnosprawności wynikającej z powikłań leczenia radioterapeutycznego. Ryzyko wystąpienia odczynu popromiennego narasta wraz z nasileniem wielochorobowości. Związane z wiekiem ograniczenie rezerwy czynnościowej wszystkich narządów nakazuje zwrócić szczególną uwagę na ochronę narządów krytycznych.

Z powodu wieku starsi pacjenci zbyt rzadko są włączani do badań klinicznych. Przyczynia się to do niedostatecznej wiedzy na temat zastosowania radioterapii w tej grupie chorych. Konsekwencją tego jest fakt, że często u starszych pacjentów stosowane jest leczenie niewystarczająco agresywne ze względu na jego toksyczność i obawę przed wystąpieniem poważnych działań niepożądanych, jak również w obawie przed znacznym pogorszeniem jakości życia chorych. Dane dotyczące wystąpienia ostrego oraz późnego odczynu popromiennego są zbyt skąpe, aby móc jednoznacznie sformułować zalecenia postępowania radioterapeutycznego w tej grupie chorych. Dane dostępne w piśmiennictwie wskazują na możliwość zastosowania radioterapii radykalnej i paliatywnej niezależnie od wieku. Podkreślana jest konieczność zachowania ostrożności i modyfikacji dawek w przypadku prowadzenia radiochemioterapii. Radioterapia u starszych chorych musi być leczeniem wysoko zindywidualizowanym, połączonym z dokładną oceną obciążeń internistycznych i przewidywanym czasem przeżycia. Grupa robocza ds. radioterapii powołana przez Society of Geriatric Oncology (SIOG) podkreśla konieczność stosowania odpowiednich narzędzi do oceny geriatrycznej. Ocena stanu sprawności chorego jest w przypadku chorych w podeszłym wieku niewystarczająca. Całościowa Ocena Geriatryczna (COG) (Comprehensive Geriatric Assesment - CGA) jest kompleksową i wielodyscyplinarną metodą pozwalającą w pełni ocenić stan sprawności starszego pacjenta. Skala ta ocenia chorego w płaszczyźnie mentalnej, emocjonalnej, kliniczno-medycznej, funkcjonalnej oraz socjalnej. Sprawdza stan funkcjonalny oraz sprawność chorego, choroby współistniejące, zdolności poznawcze, stan psychiczny, odżywienie oraz rodzaj przyjmowanych leków.

Zastosowanie COG w praktyce klinicznej lekarza radioterapeuty pozwala na właściwy dobór pacjentów do radioterapii oraz zmniejszenie utraty sprawności chorych wynikające z zastosowania niewłaściwego leczenia. Użycie
COG jest jednak czasochłonne, i niezbędne jest podjęcie próby uproszczenia COG lub szukania alternatywnych narzędzi pomagających we właściwej kwalifikacji chorych geriatrycznych do radioterapii.

\section{Konflikt interesów: nie zgłoszono}

\author{
Dr Justyna Danielska \\ Zakład Radioterapii, Uniwersytet Medyczny w Łodzi \\ e-mail:justyna_danielska@gazeta.pl
}

Otrzymano i przyjęto do druku: 4 lipca 2015 r.

Na podstawie wykładu "Chory w podeszłym wieku jako kandydat do intensywnego leczenia onkologicznego" prof. Jacka Fijutha wygłoszonego podczas Warszawskiej Konferencji Onkologicznej 28 listopada $2014 \mathrm{r}$.

\section{Piśmiennictwo}

1. Główny Urząd Statystyczny: http://stat.gov.pl

2. Williams M, Hadler NM. Sounding board. The illness as the focus of geriatric medicine. N Engl J Med 1983; 308: 1357-1360.

3. Howlader N, Noone AM, Krapcho M i wsp. SEER Cancer Statistics Review, 1975-2009 (Vintage 2009 Populations). National Cancer Institute Bethesda, MD.

4. Bouchardy C, Rapiti E, Fioretta G i wsp. Undertreatment strongly decreases prognosis of breast cancer in elderly women. $J$ Clin Oncol 2003; 21: 3580-3587.

5. Schonberg MA, Marcantonio ER, Li D i wsp. Breast cancer among the oldest old: tumor characteristics, treatment choices, and survival. J Clin Oncol 2010; 28: 2038-2045.

6. Hughes KS, Schnaper LA, Bellon JR i wsp. Lumpectomy plus tamoxifen with or without irradiation in women age 70 years or older with early breast cancer: long-term follow-up of CALGB 9343. J Clin Oncol 2013; 31: 2382-2387.

7. Krajowy Rejestr Nowotworów: http://onkologia.org.pl

8. Martijn H,Vulto JC. Should radiotherapy be avoided or delivered differently in elderly patient with rectal cancer? Eur J Cancer 2007; 43: 2301-2306.

9. Talarico L, Chen G, Pazdur R. Enrollment of elderly patients in clinical trials for cancer drug registration: a 7-year experience by the US Food and Drug Administration. J Clin Oncol 2004; 22: 4626-4631.

10. Pasetto LM, Frisco ML, Pucciarelli S i wsp. Anticancer Res 2006; 26 : 319-3923.

11. Margalit DN, Mamon HJ, Ancukiewicz M i wsp. Tolerability of combined modality therapy for rectal cancer in elderly patients aged 75 years and older. Int J Radiat Oncol Biol Phys 2011; 81: e735-741.

12. Neugut Al, Fleischauer AT, Sundararajan V i wsp. Use of adjuvant chemotherapy and radiation therapy for rectal cancer among the elderly: a population based study. J Clin Oncol 2002; 20: 2643-2650.

13. Colorectal Cancer Colaborative Group. Adjuvant radiotherapy for rectal cancer: a systematic overview of 8507 patients from 22 randomized trials. Lancet 2001; 358:1291-1304.

14. Syrigos KN, Karachalios D, Karapanagiotou EM i wsp. Head and neck cancer in the elderly: an overview on the treatment modalities. Cancer Treat Rev 2009; 35: 237-245.

15. Pignon $T$, Horiot JC, Van den Bogaert W i wsp. No age limit for radica radiotherapy in head and neck tumours. Eur J Cancer 1996; 32A: 2075-2081.

16. Cooper JS, Pajak TF, Forastiere AA i wsp. Postoperative concurrent radiotherapy and chemotherapy for high-risk squamous-cell carcinoma of the head and neck. NEngl J Med 2004; 350: 1937-1944.

17. Bernier J, Domenge C, Ozsahin M i wsp. Postoperative irradiation with or without concomitant chemotherapy for locally advanced head and neck cancer. N Engl J Med 2004; 350: 1945-1952.

18. Pignon JP, le Maitre A, Maillard E i wsp. Meta-analysis of chemotherapy in head and neck cancer (MACH-NC): an update on 93 randomised trials and 17,346 patients. Radiother Oncol 2009; 92: 4-14.

19. Forastiere AA, Goepfert $\mathrm{H}$, Maor M i wsp. Concurrent chemotherapy and radiotherapy for organ preservation in advanced laryngeal cancer. N Engl J Med 2003; 349: 2091-2098. 
20. Machtay M, Moughan J, Trotti A i wsp. Factors associated with severe late toxicity after concurrent chemoradiation for locally advanced head and neck cancer: an RTOG analysis. J Clin Oncol 2008; 26: 3582-3589.

21. Maggiore RJ, Curran EK, Witt ME i wsp. Survival and selected outcomes of older adults with locally advanced head/neck cancer treated with chemoradiation therapy. J Geriatr Oncol 2013; 4: 327-333.

22. Bonner JA, Harari PM, Giralt J i wsp. Radiotherapy plus cetuximab for locoregionally advanced head and neck cancer: 5-year survival data from a phase 3 randomised trial, and relation between cetuximab-induced rash and survival. Lancet Oncol 2010; 11: 21-28.

23. SIOG Society of Geriatric Oncology recommendations.

24. Grieg NH, Ries LG, Yancik R i wsp. Increasing annual incidence of primary malignant brain tumors in the elderly. J Nat/ Cancer Inst 1990; 82: 1621-1624.

25. Roa W, Brasher PM, Bauman G i wsp. Abbreviated course of radiation therapy in older patients with glioblastoma multiforme: a prospective randomized trial. J Clin Oncol 2004; 22: 1583-1588.

26. Keime-Guibert F, Chinot O, Taillandier L i wsp. Radiotherapy for glioblastoma in the elderly. NEngl J Med 2007; 356: 1527-1535.
27. Stupp R, Hegi M, Mason W i wsp. Effects of radiotherapy with concomitant and adjuvant temozolomide versus radiotherapy alone on survival in glioblastoma in a randomized phase III study: 5-year analysis of the EORTC-NCIC trial. Lancet Oncol 2009; 10: 459$-466$.

28. Malmstrom A, Gronberg B, Marosi C i wsp. Temozolomide versus standard 6-week radiotherapy versus hypofractionated radiotherapy in patients older than 60 years with glioblastoma: the Nordic randomized, phase 3 trial. Lancet Oncol 2012; 13: 916-926.

29. Roa W, Brasher PM, Bauman G i wsp. Abbreviated course of radiation therapy in older patients with glioblastoma multiforme: a prospective randomized trial. J Clin Oncol 2004; 22: 1583-1588.

30. Droz JP, Balducci L, Bolla M i wsp. Management of prostate cancer in older men: recommendations of a working group of the International Society of Geriatric Oncology. BJU Int 2010; 106: 462-469.

31. Shahinian VB, Kuo YF, Freeman JL i wsp. Risk of fracture after andro-gen deprivation for prostate cancer. N Engl J Med 2005; 352: 154 -164 .

32. National Comprehensive Cancer Network http://www.ncen.org 